\title{
ADQUISICIÓN Y TRANSMISIÓN DE BIENES INMUEBLES POR MATRIMONIOS ENTRE EXTRANJEROS: SU INSCRIPCIÓN EN EL REGISTRO DE LA PROPIEDAD
}

\author{
Acquisition and transmission of Real Estate \\ by foreign spouses: Access to the Land Registry
}

\author{
ESPERANZA CASTELLANOS RUIZ \\ Universidad Carlos III de Madrid \\ esperanza.castellanos@uc3m.es
}

Cómo citar/Citation

Castellanos Ruiz, E. (2018).

Adquisición y transmisión de bienes inmuebles por matrimonios entre extranjeros: su inscripción en el registro de la propiedad.

Derecho Privado y Constitución, 33, 11-46.

doi: https://doi.org/10.18042/cepc/dpc.33.01

(Recepción: 30/06/2018; aceptación tras revisión: 24/09/2018; publicación: 28/11/2018)

\section{Resumen}

El objeto de este estudio es determinar el régimen jurídico de la inscripción en el Registro de la Propiedad de las adquisiciones de bienes inmuebles situados en España por matrimonios extranjeros. En primer lugar, para ello es necesario determinar el régimen económico de los matrimonios extranjeros cuando se adquiere o se enajena por parte de los dos cónyuges un bien inmueble sito en España, teniendo en cuenta que queda sujeto a un ordenamiento extranjero. En segundo lugar, las reglas que determinan el régimen económico matrimonial no solo afectan a los cónyuges sino también a los terceros que se relacionan con ellos, sobre todo en el momento de enajenación de los bienes inmuebles inscritos en el Registro de la Propiedad cuando 
los titulares son dos contrayentes extranjeros. En tercer lugar, las falsas apariencias y el riesgo patrimonial están, en muchas ocasiones, latentes tanto cuando adquiere los bienes inmuebles el matrimonio de extranjeros como en una fase posterior de enajenación del bien adquirido por el matrimonio a un tercero cuando el Registro de la Propiedad no refleja exactamente el estado real de los bienes.

\title{
Palabras clave
}

Registro de la Propiedad; matrimonio extranjero; régimen económico matrimonial; arts. 9.2 y 9.3 CC; Reglamento (UE) 2016/1103.

\begin{abstract}
Purpose of this work is to determine the legal status of the access to the Land Registry of real estate located in Spain and held by foreign spouses. Firstly, it is necessary to specify the influence of the matrimonial property governed by foreign law on the property of an immovable located in Spain when acquired by both spouses. Secondly, the rules that determine the matrimonial property regime affects not only the spouses but also third parties who might buy the real estate registered in the Land Registry. Thirdly, patrimonial risks are, in many cases, latent when real estate is acquired by foreign spouses and then sold to third parties since the Land Registry could not exactly reflect the real legal status of estates.
\end{abstract}

\section{Keywords}

Land Registry; foreign marriage; marriage dependent spouses; arts. 9.2 y 9.3 CC; Regulation (UE) 2016/1103. 


\section{SUMARIO}

I. INTRODUCCIÓN. II. PUBLICIDAD DEL RÉGIMEN ECONÓMICO DEL MATRIMONIO SOMETIDO A UNA LEY EXTRANJERA. III. INSCRIPCIÓN DE LOS BIENES INMUEBLES PROPIEDAD DE CÓNYUGES EXTRANJEROS EN EL REGISTRO DE LA PROPIEDAD ESPAÑOL: 1. Consideraciones introductorias. 2. Determinación del régimen económico del matrimonio: 2.1. Adquisición de la propiedad «para el régimen matrimonial» y enajenación posterior del inmueble. 2.2. Excepciones: régimen económico matrimonial acreditado y carácter privativo de un bien inmueble en un régimen de comunidad. 3 . Consecuencias de no hacer constar el régimen económico matrimonial. 4. Inmuebles inscritos sin constancia del régimen económico matrimonial de sus propietarios y ejecución hipotecaria. 5. Cónyuges sin régimen económico matrimonial. 6. Menciones utilizadas por los notarios españoles para hacer constar el régimen económico matrimonial: 6.1. La mención de adquisición «para su régimen de gananciales». 6.2. La mención «en el régimen legal de su nacionalidad». IV. INSCRIPCIÓN DEL RÉGIMEN ECONÓMICO DEL MATRIMONIO EN EL REGISTRO CIVIL ESPAÑOL: 1. Publicidad del régimen económico del matrimonio, en defecto de capitulaciones matrimoniales. 2. Publicidad de las capitulaciones matrimoniales: 2.1. Indicación registral voluntaria de las capitulaciones matrimoniales. 2.2. Validez de las capitulaciones matrimoniales otorgadas en el extranjero. 2.3. Discrepancia entre lo inscrito en el Registro Civil y lo inscrito en el Registro de la Propiedad. 2.4. Discrepancia entre lo inscrito en el Registro Civil y lo inscrito en el Registro Mercantil español. Biblografía.

\section{INTRODUCCIÓN}

Contratar con personas casadas conlleva la necesidad de determinar la responsabilidad de los cónyuges frente a terceros. Por ello, para evitar riesgos patrimoniales, es preciso que los terceros conozcan o puedan conocer el régimen económico matrimonial del cónyuge o de los cónyuges que se relaciona con ellos. Este riesgo puede multiplicarse en el caso de contratar con matrimonios cuyo régimen económico queda sujeto a un ordenamiento extranjero. Los problemas surgen fundamentalmente tanto en relación con los matrimonios de extranjeros sujetos a un régimen económico matrimonial pactado por los cónyuges en capitulaciones matrimoniales o documento homólogo como 
en relación con los matrimonios extranjeros cuyo régimen económico viene determinado por una ley foránea (Calvo Caravaca y Carrascosa González, 2017a: 250).

Las reglas que determinan el régimen económico matrimonial, por tanto, interesan o afectan a los cónyuges, pero fundamentalmente a los terceros que se relacionan con ellos (poderes dispositivos sobre los bienes, sistema de responsabilidad patrimonial). Por tal razón, para evitar sorpresas, cuando se adquiere un bien inmueble situado en España por parte del matrimonio extranjero o se enajena el bien inmueble propiedad del matrimonio extranjero a un tercero es necesario un sistema de publicidad adecuado.

El objeto de este estudio es determinar cómo se da publicidad al régimen económico de los matrimonios extranjeros cuando se adquiere o se enajena por parte de los dos cónyuges un bien inmueble sito en España. Se trata de una cuestión innegablemente práctica que no está regulada de forma satisfactoria en el derecho internacional privado español. Dado que notarios y registradores son los dos grandes valedores de la seguridad jurídica preventiva, este estudio parte fundamentalmente de la doctrina de la Dirección General de los Registros y del Notariado — en adelante DGRN — en esta materia.

El sistema español de seguridad jurídica preventiva tiene como uno de sus pilares básicos la publicidad de la titularidad del dominio y demás derechos reales sobre bienes inmuebles. De ahí que la determinación de la titularidad deba quedar reflejada en los asientos del Registro de la Propiedad, que, en general, tiene un alcance limitado a los actos y contratos relativos a los derechos reales sobre inmuebles situados en España. Tratándose de personas casadas, la titularidad queda afectada por la existencia, convencional o legal, del régimen económico-matrimonial que determina el ejercicio y extensión del derecho. Para que dichas circunstancias puedan ser conocidas por terceros, el Registro debe publicarlas, y de ahí que nuestro ordenamiento exija la debida constancia de cuál sea el régimen económico matrimonial al que está sujeto el titular registral (RDGRN de 2 abril de 2018). Es, por tanto, la lex registrationis española la que conmina a que, en las titularidades inscritas en el Registro de la Propiedad en favor de personas casadas, conste el régimen económico al que se encuentran sujetas, si bien dicho régimen económico también se hace constar previamente en las escrituras públicas de transmisión y de adquisición del bien.

Tanto los notarios como los registradores de la propiedad, complementariamente, desempeñan un papel fundamental en la seguridad jurídica preventiva, por lo que el documento público, así como la inscripción, debe reflejar de forma cierta todas aquellas circunstancias referentes a la capacidad de los otorgantes, como la edad o las circunstancias modificativas de la capacidad, el estado civil, la nacionalidad, la vecindad civil o el régimen económico 
matrimonial, que incidan de presente o puedan incidir de futuro en la validez del negocio jurídico o de la relación jurídico-real que se constituya (RDGRN de 2 abril de 2018, 25 de julio y 31 de agosto de 2017).

\section{PUBLICIDAD DEL RÉGIMEN ECONÓMICO DEL MATRIMONIO SOMETIDO A UNA LEY EXTRANJERA}

Cuando dos cónyuges, cuyo matrimonio está sujeto a un ordenamiento extranjero, adquieren un bien inmueble situado en España es necesario determinar su régimen económico matrimonial con el fin de indicar la disciplina que rige la titularidad adquirida: cuál es la proporción en la que compran cada uno de ellos, si lo adquieren pro indiviso, o si lo adquiere uno solo de los cónyuges con carácter privativo.

En España, la ley aplicable al régimen económico del matrimonio en sede de derecho internacional (e interregional) privado se regula por los arts. 9.2 CC — que regula la ley aplicable a todos los efectos del matrimonio, personales y patrimoniales - y $9.3 \mathrm{CC}$ - que regula la ley aplicable a la validez de los pactos o capitulaciones matrimoniales - (Calvo Caravaca y Carrascosa González, 2017b: 213; Rodríguez Rodrigo, 2017; Quinzá Redondo, 2016).

$\mathrm{El}$ art. 9.2 CC, a través de puntos de conexión «en cascada», señala que «los efectos del matrimonio se regirán por la ley personal común de los cónyuges al tiempo de contraerlo; en defecto de esta ley, por la ley personal o de la residencia habitual de cualquiera de ellos, elegida por ambos en documento auténtico otorgado antes de la celebración del matrimonio; a falta de esta elección, por la ley de la residencia habitual común inmediatamente posterior a la celebración; $y$, a falta de dicha residencia, por la del lugar de celebración del matrimonio» (Calvo Caravaca y Carrascosa González, 2017b: 225; Rodríguez Rodrigo, 2017).

$\mathrm{El}$ art. 9.3 CC, por su parte, es una norma de conflicto especial en relación con el art. 9.2 CC, materialmente orientada, que trata de salvar la eficacia de los capítulos siempre que puedan acogerse a cualquiera de las legislaciones que menciona: la que rija los efectos del matrimonio (art. 9.2 CC), la de la nacionalidad o la de la residencia de cualquiera de las partes al tiempo de su otorgamiento (Rodríguez Rodrigo, 2017; Calvo Caravaca y Carrascosa González, 2017b: 240).

Hay que tener en cuenta, sin embargo, que la aplicación de estas dos normas de conflicto tiene los días contados, pues el 8 de julio de 2016 se publicaron dos normas europeas sobre relaciones patrimoniales de parejas. Estos textos son: 
a) El Reglamento (UE) 2016/1103, del Consejo, de 24 de junio de 2016, por el que se establece una cooperación reforzada en el ámbito de la competencia, la ley aplicable, el reconocimiento y la ejecución de resoluciones judiciales en materia de regímenes económicos matrimoniales (DOUE L183, de 8 julio 2016, pp. 1-29) —RREM, en adelante-.

b) El Reglamento (UE) 2016/1104, del Consejo, de 24 de junio de 2016, por el que se establece una cooperación reforzada en el ámbito de la competencia, la ley aplicable, el reconocimiento y la ejecución de resoluciones en materia de efectos patrimoniales de las uniones registradas (DOUE L183, de 8 julio 2016, pp. 30-56). Según el primer párrafo del art. 70, la entrada en vigor se produjo veinte días después de su publicación en el Diario Oficial de la Unión Europea.

El RREM será aplicable treinta meses después de su entrada en vigor (art. 70.2). Se aplicará, por tanto, a las acciones planteadas y a las resoluciones dictadas a partir del 29 de enero de 2019 (art. 69.1). En cuanto a la ley aplicable, es decir, las normas de conflicto aplicables a los efectos del matrimonio, el Reglamento se aplica a los matrimonios celebrados o a las elecciones de ley realizadas después del 29 de enero de 2019 (art. 69.3). Así, los arts. 22 —elección de la ley aplicable - y 26 - ley aplicable en defecto de elección - regulan la ley aplicable al régimen económico matrimonial.

El art. 22 RREM introduce el criterio de la autonomía de la voluntad para determinar la ley aplicable al régimen económico matrimonial pactado o legal, en sintonía con otros reglamentos europeos (Jayme, 2009; Campuzano Díaz, 2008; Farrugia, 2011; Rodríguez Rodrigo, 2018, Yetamo, 2010).

Así, el art. 22 RREM (elección de la ley aplicable) señala:

1. Los cónyuges o futuros cónyuges podrán designar o cambiar de común acuerdo la ley aplicable a su régimen económico matrimonial, siempre que se trate de una de las siguientes leyes:

a) la ley del Estado en el que los cónyuges o futuros cónyuges, o uno de ellos, tengan su residencia habitual en el momento de la celebración del acuerdo, o

b) la ley del Estado de la nacionalidad de cualquiera de los cónyuges o futuros cónyuges en el momento en que se celebre el acuerdo.

2. Salvo acuerdo en contrario de los cónyuges, todo cambio de la ley aplicable al régimen económico matrimonial efectuado durante el matrimonio solo surtirá efectos en el futuro.

3. Ningún cambio retroactivo de la ley aplicable efectuado en virtud del apartado 2 afectará negativamente a los derechos de terceros derivados de dicha ley. 
El art. 26 RREM determina la ley aplicable en defecto de elección por las partes, a través de una serie de puntos de conexión en cascada (Barrière Brousse, 2017; Bonomi, 2014; Godechot-Patris, 2016; Joubert, 2017; Marino, 2017; Péroz y Fongaro, 2017; Rodríguez Rodrigo, 2017; Rodríguez Rodrigo, 2018; Vismara, 2017):

1. En defecto de un acuerdo de elección con arreglo a lo dispuesto en el artículo 22, la ley aplicable al régimen económico matrimonial será la ley del Estado:

a) de la primera residencia habitual común de los cónyuges tras la celebración del matrimonio, o, en su defecto,

b) de la nacionalidad común de los cónyuges en el momento de la celebración del matrimonio, o, en su defecto,

c) con la que ambos cónyuges tengan la conexión más estrecha en el momento de la celebración del matrimonio, teniendo en cuenta todas las circunstancias.

2. Si los cónyuges tienen más de una nacionalidad común en el momento de la celebración del matrimonio, solo se aplicarán las letras a) y c) del apartado 1 .

3. A modo de excepción y a instancia de cualquiera de los cónyuges, la autoridad judicial que tenga competencia para resolver sobre el régimen económico matrimonial podrá decidir que la ley de un Estado distinto del Estado cuya ley sea aplicable en virtud del apartado 1, letra a), regirá el régimen económico matrimonial si el demandante demuestra que:

a) los cónyuges tuvieron su última residencia habitual común en ese otro Estado durante un período de tiempo considerablemente más largo que en el Estado designado en virtud del apartado 1, letra a), y

b) ambos cónyuges se basaron en la ley de ese otro Estado para organizar o planificar sus relaciones patrimoniales.

La ley de ese otro Estado solo se aplicará desde la celebración del matrimonio, a menos que uno de los cónyuges no esté de acuerdo. En este último caso, la ley de ese otro Estado surtirá efecto a partir del establecimiento de la última residencia habitual común en dicho Estado.

La aplicación de la ley de ese otro Estado no afectará negativamente a los derechos de terceros derivados de la ley aplicable en virtud del apartado 1, letra a).

El presente apartado no se aplicará cuando los cónyuges hayan celebrado capitulaciones matrimoniales con anterioridad al establecimiento de su última residencia habitual común en ese otro Estado. 
El ámbito de aplicación personal del Reglamento europeo es erga omnes, por lo que el texto normativo no exige ninguna condición personal de los contrayentes para que sea aplicable. Por tanto, sus normas de conflicto se aplican con independencia del domicilio, residencia habitual o nacionalidades de los cónyuges (Rodríguez Rodrigo, 2018: 167). Y además tiene carácter universal, con lo cual las normas de conflicto europeas pueden remitir tanto a la ley de un Estado miembro como a la de un tercer Estado.

En definitiva, a partir del 29 de enero de 2019 se aplicará el RREM a las acciones interpuestas en relación con el régimen económico matrimonial; sin embargo, si el asunto se refiere a un matrimonio celebrado antes del $30 \mathrm{de}$ enero de 2019, la autoridad española competente debe acudir a sus normas de producción interna para determinar el derecho aplicable, es decir, a las normas de conflicto recogidas en los arts. 9.2 y 9.3 CC. También, por otro lado, los acuerdos de elección de ley realizados antes del 30 de enero de 2019 no son válidos en el marco del Reglamento. En definitiva, parece que aún queda margen de aplicación a los arts. 9.2 y 9.3 CC, a pesar de la existencia del Reglamento de la UE.

Ahora bien, el RREM no resuelve el problema de la inscripción en el Registro de la Propiedad de los bienes inmuebles situados en España adquiridos por cónyuges extranjeros. Esta inscripción se rige siempre por la ley española, como lex registrationis o lex loci. Es, por tanto, la ley del Estado a cuyo cargo se halla el Registro la que debe concretar las «modalidades» de la publicidad registral: inscripción, mención, anotación y efectos de dichas modalidades de acceso a los registros públicos (Calvo Caravaca y Carrascosa González, 2017b: 250). La ley del lugar donde deba practicarse la inscripción se aplica en virtud del art. 10.1 CC, que indica que la "publicidad» de los derechos reales se regirá por la ley del lugar donde estos se hallen (Calvo Caravaca y Carrascosa González, 2017b: 251), es decir, la lex loci. Esta ley es aplicable tanto si se trata de matrimonios celebrados con anterioridad al 29 de enero de 2019 como si se trata de matrimonios celebrados después del 29 de enero de 2019.

En definitiva, tratándose de adquisiciones llevadas a cabo por personas cuyo régimen económico matrimonial esté sujeto a una ley extranjera, la regla en materia de inscripción de los bienes inmuebles situados en España es la misma que si están sujetos a la ley española, «pues la finalidad de publicar una situación jurídica cierta, de conformidad con el principio de especialidad, no se ve modificada por dicha circunstancia» (RDGRN de 15 de julio de 2011).

La cuestión, sin embargo, es más compleja, pues la determinación de cuál sea el régimen aplicable implica el conocimiento del derecho extranjero, lo que no es obligado para los funcionarios españoles. Esta oposición entre la exigencia legal de publicar en toda su extensión el derecho adquirido y las dificultades para determinar cuál es el régimen matrimonial legalmente aplicable 
ha sido cuestión de preocupación ya desde antiguo para nuestra jurisprudencia y para la DGRN. A esta dificultad pretende dar respuesta el art. $92 \mathrm{RH}$.

Ahora bien, debe tenerse presente que la entrada en juego de un ordenamiento extranjero no supone la renuncia a la determinación de la situación jurídica publicada ni que el notario español pueda adoptar una actitud pasiva. De un lado, el artículo $159 \mathrm{RN}$ no hace distinción alguna, por lo que el autorizante debe indagar la situación de los otorgantes a fin de averiguar si existen capítulos o contrato matrimonial entre ellos para proceder, tal y como exige dicho precepto, testimoniando, en su caso, los aspectos particulares que puedan ser relevantes al efecto (RDGRN de 2 de abril de 2018 y de 15 de junio de 2009). De otro lado, el notario español está obligado a aplicar la norma de conflicto europea o española de producción interna (art. 12.6 CC) y a determinar, con arreglo a dicha norma, la ley material que resulte aplicable al régimen económico de los cónyuges. Así, aunque el notario desconozca el contenido de la ley material extranjera, debe reflejar debidamente en la comparecencia del instrumento público cuál es la norma aplicable a las relaciones patrimoniales entre cónyuges. «En definitiva, no debe confundirse la falta de obligatoriedad de conocer el Derecho extranjero con el deber de determinar cuál es la legislación extranjera aplicable» (RDGRN de 2 de abril de 2018 y 15 de julio de 2011).

Las reglas que determinan el régimen económico matrimonial afectan principalmente a los terceros que se relacionan con ambos o con alguno de los cónyuges, sobre todo en el momento de enajenación de los bienes inmuebles inscritos en el Registro de la Propiedad cuando la titularidad corresponda a cónyuges cuyo régimen económico matrimonial se halle sometido a una ley extranjera. Las falsas apariencias deben evitarse no solo cuando adquiere los bienes inmuebles el matrimonio, sino sobre todo en la fase posterior de enajenación del bien adquirido.

\section{INSCRIPCIÓN DE LOS BIENES INMUEBLES PROPIEDAD DE CÓNYUGES EXTRANJEROS EN EL REGISTRO DE LA PROPIEDAD ESPAÑOL}

\section{CONSIDERACIONES INTRODUCTORIAS}

Las capitulaciones matrimoniales acceden al Registro de la Propiedad de forma incidental, bien como título principal atributivo del dominio u otros derechos reales o bien como complemento necesario de otro título atributivo, para determinar el régimen económico matrimonial bajo el que se adquiere. 
El Registro, con carácter general, debe expresar el régimen jurídico de lo que se adquiere, y, en este sentido, la regla 9. ${ }^{\mathrm{a}}$ del art. $51 \mathrm{RH}$ exige que se haga constar el régimen económico matrimonial. El art. 51.9.1. ${ }^{\circ} \mathrm{RH}$ señala que, en las inscripciones en el Registro de la Propiedad de bienes inmuebles, respecto a persona a cuyo favor se practique la inscripción y aquella de quien proceda el bien o derecho que se inscriba se expresará:

[...] si se trata de personas físicas el nombre y apellidos; el documento nacional de identidad; si es mayor de edad o, en otro caso, la edad que tuviera, precisando, de estar emancipado, la causa; si el sujeto es soltero, casado, viudo, separado o divorciado y, de ser casado y afectar el acto o contrato que se inscriba a los derechos presentes o futuros de la sociedad conyugal, el régimen económico matrimonial y el nombre y apellidos y domicilio del otro cónyuge; la nacionalidad y la vecindad civil del sujeto si se acreditan o manifiestan; y el domicilio con las circunstancias que lo concreten.

Por tanto, el régimen económico del matrimonio es obligatorio que conste si se trata de la inscripción de un bien inmueble que se vea afectado por el régimen económico de los cónyuges. Cuando este régimen económico matrimonial se rige por una ley extranjera, conforme a los arts. 9.2 o 9.3 CC (o conforme a los arts. 22 o 26 RREM, en relación con los matrimonios que se celebren después del 29 de enero de 2019), surge el problema de determinar si la inscripción de la propiedad de ese bien se ve o no afectado por el régimen económico matrimonial de los cónyuges.

No obstante, dadas las dificultades que puede entrañar la determinación del régimen económico matrimonial, tras la reforma llevada a cabo en 1982, el art. $92 \mathrm{RH}$ dispone que "cuando el régimen económico-matrimonial del adquirente o adquirentes casados estuviere sometido a legislación extranjera, la inscripción se practicará a favor de aquél o aquéllos haciéndose constar en ella que se verifica con sujeción a su régimen matrimonial, con indicación de éste, si constare».

En realidad, la norma citada difiere el problema de acreditación del derecho extranjero al momento de la enajenación del bien inmueble cuya adquisición es objeto de inscripción, salvo que la consintieran ambos cónyuges, pero debe tenerse presente que la entrada en juego de un ordenamiento extranjero no supone la renuncia a la determinación de la situación jurídica publicada.

\section{DETERMINACIÓN DEL RÉGIMEN ECONÓMICO DEL MATRIMONIO}

La celebración del matrimonio lleva aparejada una serie de efectos para los cónyuges, efectos que pueden clasificarse en efectos personales y efectos 
patrimoniales. En relación con los segundos, cabe afirmar que el matrimonio implica una serie de relaciones patrimoniales o económicas entre los cónyuges y entre estos y los terceros que se regirán por las normas del régimen económico matrimonial que los propios cónyuges hayan elegido o por el régimen legal supletorio previsto por la legislación correspondiente reguladora de los efectos del matrimonio. Sin duda, la determinación del régimen económico matrimonial puede influir sobre el poder de disposición que cada cónyuge ostenta respecto de determinados bienes integrantes del patrimonio, tanto comunes como privativos (como en el caso de la vivienda familiar). Por tanto, es necesario que en la escritura calificada conste determinado el régimen económico matrimonial, de modo que el registrador pueda dar debido cumplimiento a las previsiones establecidas en el citado art. $18 \mathrm{LH}$. Sin embargo, a veces no hay constancia del régimen económico del matrimonio, lo que plantea graves problemas.

De este modo, se hace necesario precisar el régimen jurídico de la inscripción en el Registro de la Propiedad de tales adquisiciones teniendo en cuenta la doctrina de la DGRN.

\subsection{Adquisición de la propiedad "para el régimen matrimonial» y enajenación posterior del inmueble}

Es usual que, en adquisiciones de inmuebles realizadas por cónyuges extranjeros de nacionalidad común, cuyo matrimonio se rija por una ley extranjera, se haga constar en la escritura pública que adquieren «conforme a su régimen matrimonial». La causa de este modo de proceder se encuentra en que los notarios y registradores que intervienen en estas compraventas no tienen por qué conocer la disciplina de este régimen matrimonial, y por ello, al amparo del art. $92 \mathrm{RH}$, se consigna en la correspondiente inscripción que la adquisición se hace con arreglo a «su régimen económico matrimonial».

Así, frente a la regla general de nuestro sistema registral, que exige que esté claramente determinada la extensión de los derechos inscritos en el Registro de la Propiedad (art. 51.6. ${ }^{\mathrm{a}} \mathrm{RH}$ ), y aunque, desde un punto de vista estrictamente dogmático, para la adquisición de un bien por extranjero casado debería acreditarse el régimen económico en ese momento, a fin de inscribirlo con especificación del régimen de la titularidad, tal y como preceptúa el art. 51.9. a a) RH, estas reglas están ciertamente flexibilizadas para los supuestos de inscripción de bienes a favor de adquirentes casados sometidos a legislación extranjera, pues no se exige la acreditación a priori del régimen económico matrimonial, siendo suficiente que la inscripción se practique a favor del adquirente o adquirentes casados, haciéndose constar en la inscripción que se 
verificará con sujeción a su régimen matrimonial, tal y como señala el art. 92 RH (Calvo Caravaca y Carrascosa González, 2017b: 255).

En efecto, teniendo en cuenta, por un lado, la problemática que plantea la prueba del régimen económico matrimonial sujeto a legislación extranjera, y, por otro, que lo determinante es el momento de la disposición del bien y el régimen aplicable en ese preciso momento, y no el régimen vigente en el de la adquisición, la DGRN, primero, y el art. $92 \mathrm{RH}$, después (desde la reforma de 1982), asumieron que la solución más acertada consiste en aplazar tal prueba para el momento de la enajenación o gravamen posterior, inscribiéndose la adquisición sin necesidad de expresar el régimen en la inscripción, bastando con una mera referencia genérica al régimen aplicable «con sujeción a su régimen matrimonial» («con indicación de éste, si constare» expresa la disposición in fine de ese precepto reglamentario), difiriendo la prueba al momento de la enajenación posterior (RDGRN de 16 de diciembre de 2002).

Ahora bien, en el momento en que el bien adquirido con sujeción a un régimen económico matrimonial extranjero sea objeto de un acto de disposición no es posible mantener la indeterminación y, en consecuencia, debe acreditarse el contenido y la vigencia del derecho extranjero concreto aplicable al caso. Como ya ha indicado la DGRN en diversas resoluciones (RDGRN de 29 de octubre de 2002; 3, 27 y 28 de enero de 2003; 24 de febrero de 2003; 19 de diciembre de 2003; 26 de febrero de 2008; 15 de julio de 2011; 14 de octubre de 2013; 16 de junio de 2014; 28 de octubre de 2015; 4 de diciembre de 2015, y 3 de mayo de 2016), "el singular régimen de constancia del régimen económico-matrimonial de los cónyuges extranjeros en la inscripción de los bienes y derechos que adquieren, previsto en el artículo $92 \mathrm{RH}$, difiere el problema al momento de la enajenación posterior, pues en tal momento es preciso el conocimiento del Derecho aplicable al caso concreto, en cuanto a las reglas que disciplinan el régimen de disposición del bien y requisitos que el mismo impone».

Dicho régimen no se aplicará, según el criterio asentado en las citadas resoluciones, "si la enajenación o el gravamen se realizan contando con el consentimiento de ambos cónyuges (enajenación voluntaria), o demandando a los dos (enajenación forzosa)» (RDGRN de 22 de octubre de 2001, 29 de octubre de 2002, 23 de noviembre de 2002, 15 de marzo de 2003, 7 de julio de 2006, 7 de marzo de 2007, 15 de julio de 2011, 3 de mayo de 2016, 5 de marzo de 2018, y 2 de abril de 2018).

Como la legitimación registral no se extiende a la determinación del régimen matrimonial aplicable, existe una obligación de acreditar a posteriori el derecho extranjero y, en particular, la capacidad de los cónyuges de nacionalidad extranjera para realizar los actos dispositivos sobre los bienes o derechos inscritos en el Registro de la Propiedad, de esta forma. 
Por lo demás, la ley aplicable al régimen económico matrimonial no necesita mayor aclaración en los casos en que los dos cónyuges extranjeros tengan la misma nacionalidad, pues su régimen económico matrimonial, a falta de pacto, será el régimen legal supletorio correspondiente a su ley nacional común en el momento de contraer matrimonio, en relación con los matrimonios celebrados hasta el 29 de abril de 2019 (en virtud de los arts. 9.2 y 9.3 CC).

Cuando sea de aplicación el RREM (art. 69), en defecto de elección válida entre las partes (art. 22 RREM), la ley aplicable al régimen económico matrimonial será la ley de la primera residencia habitual común después de la celebración del matrimonio, y en su defecto, la ley de la nacionalidad común de los cónyuges en el momento de su celebración, si el matrimonio se celebra después del 29 de enero de 2019 (art. 26 RREM).

En el caso de tratarse de dos esposos de distinta nacionalidad, hay que determinar la ley aplicable a su régimen económico matrimonial, en defecto de capitulaciones matrimoniales, de acuerdo con los criterios de conexión que determinan las normas de conflicto de derecho internacional privado español contenidas en el artículo 9.2 CC, que dispone: "Los efectos del matrimonio se regirán por la ley personal común de los cónyuges al tiempo de contraerlo; en defecto de esta ley, por la ley personal o de la residencia habitual de cualquiera de ellos, elegida por ambos en documento auténtico otorgado antes de la celebración del matrimonio; a falta de esta elección, por la ley de la residencia habitual común inmediatamente posterior a la celebración, y, a falta de dicha residencia, por la del lugar de celebración del matrimonio».

Hay que tener en cuenta que el régimen económico de los esposos, de los matrimonios celebrados después del 29 de enero de 2019, ya no se rige por las leyes contenidas en el art. 9.2 CC, a falta de capitulaciones matrimoniales, sino por las recogidas en los arts. 22 (elección de ley) y 26 RREM (en defecto de elección de ley) — citados anteriormente-.

De esa manera podrá saberse:

[...] si la ley aplicable a su régimen económico-matrimonial será una ley extranjera, lo que posibilitará que de acuerdo con el artículo $92 \mathrm{RH}$ la finca se inscriba con sujeción al régimen matrimonial de esa ley nacional, sin necesidad de especificar cuál sea aquél, o por el contrario, el régimen económico-matrimonial se rige por la legislación española, por lo que de acuerdo con el artículo $51.9 \mathrm{RH}$, habría que manifestar y, en su caso, acreditar (si derivara de un pacto capitular), el régimen económico-matrimonial concreto, por afectar la adquisición que se inscribe a los derechos futuros de la sociedad conyugal (arts. 93 a 96 RH) (RDGRN de 4 de diciembre de 2015). 
Por tanto, no se podrá inscribir una escritura de compraventa si no queda acreditado, por los particulares interesados, el régimen económico del vendedor, cuando se trata de una persona casada cuyo régimen económico del matrimonio está sujeto a un derecho extranjero. Como señala la DGRN, «el notario en el ejercicio del control de legalidad y el registrador al calificar, deben conocer el régimen económico del matrimonio del vendedor al objeto de determinar si goza por sí solo de facultades dispositivas» (RDGRN de 26 de febrero de 2008, en relación con un vendedor casado francés respecto de un bien inmueble situado en España, o RDGRN de 26 de agosto de 2008, en relación con una vendedora casada británica respecto de un bien inmueble sito en España). En definitiva, para que se pueda inscribir la venta de un inmueble o su hipoteca es necesario determinar el concreto régimen económico del matrimonio y, si está sujeto a un ordenamiento jurídico extranjero, probar la vigencia y contenido del derecho extranjero.

Esta fórmula de diferir al momento de la enajenación del inmueble la acreditación del régimen económico matrimonial de los esposos extranjeros no está exenta de problemas, sobre todo en relación con cuestiones derivadas del embargo sobre ese bien. Puede tomarse como ejemplo la RDGRN de 5 de marzo de 2018. La cuestión objeto de este expediente era determinar si es inscribible un testimonio de decreto de adjudicación dictado en el seno de un procedimiento de ejecución hipotecaria, teniendo en cuenta que la finca, objeto de adjudicación, constaba inscrita en este Registro "por título de compra y conforme a su régimen legal de adquisiciones que resulte de la legislación extranjera aplicable a favor de don A. J. P. — de nacionalidad portuguesa-", siendo necesario acreditar cuál era dicho régimen a los efectos de poder calificar si el citado procedimiento de ejecución hipotecaria debía dirigirse solo contra el citado don A. J. P., o si, por el contrario, dicho procedimiento debía ir dirigido contra ambos cónyuges. Por este motivo el registrador suspende la inscripción del testimonio de un decreto de adjudicación recaído en procedimiento de ejecución hipotecaria, porque exige que también sea demandado el cónyuge portugués del titular registral. La DGRN confirma la nota de calificación del registrador partiendo de que es necesario haber demandado y requerido de pago a la esposa del demandado para poder inscribir un decreto de adjudicación de finca como consecuencia de un procedimiento de ejecución hipotecaria.

Aunque la cuestión fundamental fue que no se había demandado al cónyuge que aparecía también como titular registral, con independencia de su nacionalidad, y por tanto se había producido indefensión, según el historial registral tampoco constaba acreditado ante el registrador el contenido y vigencia del derecho extranjero, en este caso portugués, aplicable al régimen económico matrimonial del titular registral y, en particular, a la capacidad y 
poder de disposición del mismo para realizar los actos dispositivos sobre los bienes o derechos inscritos en tal forma, y sin que esa falta de acreditación hubiera sido suplida por una indagación o conocimiento directo del citado derecho extranjero por parte del registrador, lo cual constituía una facultad pero no una obligación del mismo. Tampoco se había acreditado la existencia de pacto capitular alguno que determinara el concreto régimen económico matrimonial aplicable (RDRGN de 31 de agosto de 2017). Como ha señalado la DGRN reiteradamente, "cuando se inscribe un bien perteneciente a persona casada extranjera, con sujeción a su régimen económico matrimonial» (artículo 92 del Reglamento Hipotecario), se está haciendo remisión a la legislación extranjera; $y$, entre los diferentes supuestos que pueden concurrir en dicha legislación, cabe la posibilidad de que exista un régimen de comunidad» (RDGRN de 9 de julio de 2013).

La DGRN consideró que, en esas condiciones, de prosperar el recurso existía riesgo de afectar al derecho de defensa del cónyuge del titular demandado. La DGRN, de forma contundente (véase, por todas, RDGRN de 3 de noviembre de 2017), ha señalado siempre:

El principio constitucional de protección jurisdiccional de los derechos y de interdicción de la indefensión procesal, que limita los efectos de la cosa juzgada a quienes hayan sido parte en el procedimiento, garantizando así el tracto sucesivo entre los asientos del Registro, que no es sino un trasunto de la proscripción de la indefensión, exige que el titular registral afectado por el acto inscribible, cuando no conste su consentimiento auténtico, haya sido parte o, si no, haya tenido, al menos, legalmente la posibilidad de intervención en el procedimiento determinante del asiento. Así se explica que, aunque no sea incumbencia del registrador calificar la personalidad de la parte actora ni la legitimación pasiva procesal apreciadas por el juzgador ni tampoco la cumplimentación de los trámites seguidos en el procedimiento judicial (a diferencia del control que sí le compete, en cambio, sobre los trámites e incidencias esenciales de un procedimiento o expediente administrativo, si se compara el tenor del artículo 99 frente al artículo 100 del Reglamento Hipotecario), su calificación de actuaciones judiciales sí debe alcanzar, en todo caso, al hecho de que quien aparece protegido por el Registro haya sido emplazado en el procedimiento, independientemente del modo en que se haya cumplimentado ese emplazamiento, cuya falta sí debe denunciar el registrador pero cuyo modo sólo compete apreciar al juez.

Para la DGRN ello es así, aunque previamente se haya inscrito la compraventa a favor del demandado con subrogación en la carga hipotecaria que gravaba el inmueble, pretendiendo ver en ello (en cuanto a la subrogación hipotecaria) un acto de disposición que en su momento no fue objeto de reparo por parte del registrador. 
Ciertamente, la DGRN, en Resolución de 15 de julio de 2011, puso de relieve que también queda sometida a lo que establezca el ordenamiento portugués como ley aplicable a los efectos del matrimonio la posibilidad de que se trate de un negocio jurídico complejo y unitario que deba recibir el mismo trato que el que se atribuye a los supuestos de adquisición de un bien ya gravado previamente con una carga hipotecaria y que, por tanto, no fuera necesario el consentimiento concurrente del cónyuge del adquirente cualquiera sea el régimen económico del matrimonio. Pero el hecho de que se hubiera practicado la inscripción en la forma indicada en nada prejuzga el poder de disposición del citado titular sobre el inmueble ejecutado. Además, como afirmó la RDGRN de 16 de junio de 2014 en un supuesto similar al presente, «no es óbice que conste inscrita sólo la hipoteca por aquél, pues los asientos están bajo la salvaguarda de los tribunales (art. 1 Ley Hipotecaria), por lo que no se puede discutir ahora si la hipoteca debió o no estar otorgada por ambos cónyuges. Ahora lo que procede es saber si la ejecución hipotecaria procede sin intervención de la esposa del hipotecante, que figura en la inscripción de la titularidad del inmueble».

Aunque en el cuerpo de la inscripción al tiempo de identificarse al comprador se hubiera hecho constar entre sus circunstancias personales las relativas a su condición de "[...] mayor de edad, casado en régimen de separación de bienes, vecino de Lisboa — Portugal — [...] de nacionalidad portuguesa [...]», no es determinante, pues lo importante de cara a la calificación es la forma en que se practicó la inscripción «a favor de don A. J. P., conforme a su régimen legal de adquisiciones, que resulte de la legislación extranjera aplicable, por título de compra [...]», es decir, sin prejuzgar ni aclarar si la finca le correspondía como carácter privativo o bien si la misma estaba sujeta a algún régimen de comunidad de bienes.

En este sentido, como ha señalado reiteradamente la DGRN en sus resoluciones de 15 de junio de 2009 y 10 de marzo de 2014:

Si bien es cierto que en muchos casos no es tarea sencilla el determinar cuál es el régimen legal supletorio, es necesario que el notario, a la hora de redactar el instrumento público conforme a la voluntad común de los otorgantes — que deberá indagar, interpretar y adecuar al ordenamiento jurídico-, despliegue la mayor diligencia al reflejar en el documento autorizado cuál es el régimen económico matrimonial que rige entre los esposos. En tal sentido, establece el artículo 159 del Reglamento Notarial que si dicho régimen fuere el legal bastará la declaración del otorgante, lo cual ha de entenderse en el sentido de que el notario, tras haber informado y asesorado en Derecho a los otorgantes, y con base en las manifestaciones de éstos (que primordialmente versan sobre datos fácticos corno su nacionalidad o vecindad civil al tiempo de contraer matrimonio, su lugar de celebración o el de la residencia habitual y la ausencia de capítulos —cfr. artículos 9.2 y 16.3 del Código Civil—), 
concluirá que su régimen económico matrimonial, en defecto de capítulos, será el legal supletorio que corresponda, debiendo por tanto hacer referencia expresa a tal circunstancia —el carácter legal de dicho régimen — al recoger la manifestación de los otorgantes en el instrumento público de que se trate.

Si ello es así incluso en supuestos de tráfico interno sujetos al derecho español, con mayor motivo debe estimarse insuficiente la mera manifestación sobre el régimen económico matrimonial del comprador, omitiendo la referencia a su carácter legal, en los supuestos en los que el régimen económico está sujeto a una ley extranjera, teniendo en cuenta que el régimen expresado por el comprador portugués - de separación - no era el legal supletorio en Portugal (véanse arts. 1698 y 1717 de Código Civil portugués). Por todo ello, se acordó desestimar el recurso y confirmar la nota de calificación del registrador.

Esta postura ha sido fuertemente criticada por los problemas que acarrea frente a terceros, como se ha podido comprobar (Carrillo Pozo, 2011: 106; Mingorance Gonsálvez, 2010: 68).

Por ello, la DGRN, en su Resolución de 5 de marzo de 2018 - ya citada-, consideró que era mucho más conveniente determinar que el art. 92 $\mathrm{RH}$ tan solo opera, como excepción a lo dispuesto en el art. $54 \mathrm{RH}$, cuando ese régimen económico matrimonial no esté debidamente determinado, pues si está determinado no puede aplicarse. Así lo ha señalado la RDGRN de 31 de agosto de 2017, en relación con una compraventa en la que los compradores eran de nacionalidad alemana, y estaban casados conforme al régimen económico matrimonial legal de su nacionalidad — que es el de participación de ganancias, que actúa como un régimen de separación de bienes durante su vigencia-. Y como no constaba la proporción de compra de la finca el registrador negó la inscripción de la escritura de compraventa, porque al encontrarse casados los adquirentes en el régimen legal aplicable a su común nacionalidad alemana de participación de ganancias, se hacía preciso que se determinara la proporción en la que los cónyuges habían adquirido, por exigirlo así al art. 54 RH y las RRDGRN, entre otras, de 19 de diciembre de 2003 y de 10 de enero de 2004. El art. $92 \mathrm{RH}$ tan solo opera, por tanto, como excepción a lo dispuesto en el art. 54, cuando ese régimen económico matrimonial no está debidamente determinado ( 11 . Las inscripciones de partes indivisas de una finca o derecho precisarán la porción ideal de cada condueño con datos matemáticos que permitan conocerla indudablemente. 2. Esta regla se aplicará cuando las partes de un mismo bien, aun perteneciendo a un solo titular, tengan distinto carácter o distinto régimen. 3. No se considerará cumplido este requisito si la determinación se hiciere solamente con referencia a unidades de moneda, de medida superficial u otra forma análoga»). 
Ahora bien, de confirmarse esta interpretación, haría inaplicable de forma injustificada el art. $92 \mathrm{RH}$, cuya aplicación cobra sentido en casos en los que hay que aplicar un derecho extranjero, con el fin de permitir el tráfico jurídico con unas garantías suficientes, permitiendo que la inscripción se practique a favor del cónyuge comprador de la cuota respectiva, con sujeción a su régimen matrimonial.

Hasta la RDGRN de 31 de agosto de 2017, las decisiones de la DGRN tenían en común que en el caso de adquisiciones por extranjeros casados no se requería la acreditación del régimen matrimonial en el momento de la adquisición, sino en el de la enajenación. Ahora bien, con esta nueva interpretación el panorama jurídico cambia para los casados extranjeros que quieran adquirir un bien inmueble en España, pues no bastará con señalar que compran con arreglo a su régimen matrimonial.

Debido a la complicación que podía provocar esta interpretación de la DGRN en el cumplimiento de unas garantías suficientes dentro del tráfico jurídico, en una resolución posterior, de 2 abril de 2018, no mantiene ni confirma esta solución. Se trataba de una compraventa donde tres ciudadanas de nacionalidad española vendieron a dos ciudadanos de nacionalidad china una vivienda en la ciudad de Barcelona. En la escritura se hizo constar que los compradores estaban casados entre sí en el régimen establecido en la legislación de China y que compraron en un $80 \%$ la esposa y en el 20\% restante el esposo. Se niega la inscripción porque los registradores consideraban que no quedaba claro que se pudiera adquirir un bien con ese reparto de cuotas al no haberse probado tal posibilidad en el derecho chino. Sin embargo, la registradora reconoce en su calificación que el régimen económico matrimonial legal chino es de comunidad, si bien, por entender que la adquisición se realizaba por los cónyuges con carácter privativo, exigió que se acreditase que se podía realizar dicha adquisición en el derecho chino. Pero este tema no es un problema para la inscripción de la escritura de compraventa en opinión de la DGRN, pues resulta inequívocamente de la escritura calificada que los adquirentes no atribuían tal carácter privativo a sus respectivas cuotas adquiridas, por lo que no existía obstáculo para inscribirlas a nombre de cada uno de los cónyuges con sujeción a su régimen matrimonial. Será después, en el ulterior momento de su enajenación — voluntaria o forzosa - cuando habrá que acreditar si conforme al derecho chino puede la misma realizarse sin consentimiento de ambos consortes.

Hay que tener en cuenta que las adquisiciones mortis causa afectan, por regla general, a los derechos presentes o futuros de la sociedad conyugal, por lo que si el vendedor adquirió por herencia es igualmente necesario acreditar en la venta su régimen económico matrimonial, porque hay legislaciones para las que los bienes adquiridos a título gratuito están sujetos a un régimen especial 
de disposición, como en Noruega o en Suecia (RDGRN de 28 de octubre de 2015, en la que se discutía si era inscribible una escritura de compraventa en la que uno de los vendedores era un extranjero, concretamente de nacionalidad estadounidense, que, si bien manifestaba que su estado civil era de casado, no indicaba cuál era el régimen económico que regía las relaciones patrimoniales surgidas en el seno de su matrimonio).

\subsection{Excepciones: régimen económico matrimonial acreditado y carácter privativo de un bien inmueble en un régimen de comunidad}

Ahora bien, hay dos supuestos en los que no cabe el aplazamiento en la determinación del régimen económico matrimonial de los cónyuges extranjeros y, por tanto, es obligatorio acreditarlo en el momento de la adquisición del bien inmueble:

a) Si se conoce cuál es el régimen económico matrimonial de los cónyuges adquirentes, se hará constar en la inscripción registral cuál es ese concreto régimen económico matrimonial.

b) Cuando el régimen económico matrimonial es de comunidad, pero se adquiere el bien inmueble con carácter privativo por uno de los esposos.

Veamos cada uno de estos supuestos.

a) Régimen económico matrimonial acreditado

Si se conoce cuál es el régimen económico matrimonial de los cónyuges adquirentes, se hará constar en la inscripción registral cuál es ese concreto régimen económico matrimonial. No bastará, en este caso, señalar con carácter general que los esposos extranjeros adquieren con sujeción a su régimen matrimonial si el registrador conoce el régimen económico de los cónyuges. Así, por ejemplo, si se halla en un régimen de separación es necesario expresar en qué proporción adquieren cada uno de los cónyuges. Así lo ha señalado reiteradamente la DGRN (RDGRN de 29 de octubre de 2002, 3 de enero de 2003, 27 de enero de 2003, 28 de enero de 2003, 24 de febrero de 2003, 19 de diciembre de 2003 y 31 de agosto de 2017).

El modo de acreditar el régimen económico matrimonial de los adquirentes casados es diverso:

i) Puede acreditarse mediante prueba del derecho extranjero aplicable ex arts. 9.2 y $9.3 \mathrm{CC}$ o arts. 22 y 26 RREM realizada por el notario autorizante o por las partes. 
ii) Puede acreditarse mediante exhibición ante el notario de las capitulaciones matrimoniales válidas, y podrá autorizarse la venta, aunque tales capitulaciones no estén mencionadas en el Registro Civil (RDGRN de 9 enero 2008 [capitulaciones de cónyuges de nacionalidad chilena y argentina y adquisición de inmueble sito en España]). En este sentido, como declaró la RDGRN de 15 de julio de 2011, el notario debe desplegar la mayor diligencia en la averiguación de cuál es el régimen económico matrimonial de los comparecientes extranjeros, señalando textualmente la citada resolución:

[...] debe tenerse presente que la entrada en juego de un ordenamiento extranjero no supone la renuncia a la determinación de la situación jurídica publicada ni que el notario español pueda adoptar una actitud pasiva. De un lado, el artículo 159 del Reglamento Notarial no hace distinción alguna, por lo que el autorizante debe indagar la situación de los otorgantes a fin de averiguar si existen capítulos o contrato matrimonial entre ellos para proceder, tal y como exige dicho precepto, testimoniando, en su caso, los aspectos particulares que puedan ser relevantes al efecto (vid. Resolución de 15 de junio de 2009). De otro, el notario español está obligado a aplicar la norma de conflicto española (artículo 12.6 del Código Civil) y a determinar, de acuerdo a dicha norma, la ley material que resulte aplicable al régimen económico de los cónyuges. Así aunque el notario desconozca el contenido de la ley material extranjera reflejará debidamente en la comparecencia del instrumento público cuál ha de ser la norma aplicable a las relaciones patrimoniales entre cónyuges. En definitiva, no debe confundirse la falta de obligatoriedad de conocer el Derecho extranjero con el deber de determinar cuál es la legislación extranjera aplicable.

iii) Puede acreditarse mediante juicio de notoriedad cuya responsabilidad asume el notario, lo que es frecuente en la adquisición de bienes por ciudadanos británicos, pues es evidente que en Reino Unido no hay régimen económico matrimonial en sentido estricto, por lo que se equipara el de separación de bienes (RDGRN de 26 agosto 2008 [vendedora británica, titular del inmueble con sujeción a su régimen matrimonial]).

iv) Si no consta en la escritura notarial el concreto régimen económico matrimonial extranjero de los adquirentes, pero el registrador conoce el derecho extranjero aplicable y el concreto régimen económico matrimonial de los adquirentes, podrá también hacer constar en la inscripción cuál es ese concreto régimen económico matrimonial (SAP de Alicante de 15 diciembre 2005, RDGRN de 8 octubre de 2008 [esposos colombianos y acreditación por el registrador del régimen colombiano de «comunidad conyugal diferida»] (Calvo Caravaca y Carrascosa González, 2017b: 255). 


\section{a. Acreditación del Derecho extranjero por notarios y registradores}

En relación a la prueba del derecho extranjero, sobre la que no existe un instrumento en vigor ni en la Unión Europea ni en la Conferencia de La Haya, pese a los intentos realizados al efecto, ha sido objeto de nueva regulación en la Ley 29/2015, de 30 de julio, de Cooperación Jurídica Internacional en Materia Civil (en vigor desde el 20 de agosto de 2015). Debe tenerse en cuenta que el régimen de la prueba del derecho extranjero por órganos jurisdiccionales queda regulado en el art. 33 de esta ley, que no modifica ni afecta a las reglas específicas sobre aplicación extrajudicial, en particular al art. $36 \mathrm{RH}$. Conviene destacar, que los arts. 34 a 36 de esta ley, que establecen el régimen común de solicitudes de auxilio internacional para la información del derecho extranjero, son aplicables tanto a la aplicación del derecho extranjero por autoridades jurisdiccionales como por notarios y registradores (Calvo Caravaca y Carrascosa González, 2017a: 638-639).

«Esta Ley es de carácter general pero subsidiaria a la ley especial, entre las que se encuentra la legislación hipotecaria (disposición adicional primera, letra f), de la Ley 29/2015, de 30 de julio), en cuanto sea compatible con lo dispuesto la misma. Pero entre sus principios inspiradores, fundados en el artículo $24 \mathrm{CE}$, se encuentra un principio común, el de tutela efectiva que no sólo afecta a los tribunales de Justicia, sino que deberá amparar a quien busque la tutela de los registros públicos» (RDGRN de 15 de febrero de 2016).

La aplicación de la legislación extranjera queda sometida necesariamente a su acreditación ante el registrador, ya que, al igual que en el ámbito procesal el derecho extranjero ha de ser objeto de prueba (art. 281.2 LEC), también lo ha de ser en el notarial y registral (véanse, entre otras, RRDGRN de 17 de enero de 1955, 14 de julio de 1965, 27 de abril de 1999, 1 de marzo de 2005, 20 de enero de 2011, 22 de febrero de 2012, 31 de octubre de 2013 y 15 de febrero de 2016). Es cierto, no obstante, que la DGRN ya ha señalado en diversas ocasiones que la aplicación del derecho extranjero por autoridad pública que desarrolla funciones no jurisdiccionales se sujeta a reglas especiales que se apartan de la solución general contemplada en el art. 281 LEC y que se adaptan a las particularidades inherentes al ámbito extrajudicial. «En consecuencia, los preceptos mencionados son subsidiarios para el caso de que las normas especiales sobre aplicación extrajudicial del derecho extranjero no proporcionen una solución. Una de las consecuencias de este tratamiento especial es que si al registrador no le quedase acreditado de forma adecuada el contenido y vigencia del Derecho extranjero en el que se fundamenta el acto cuya inscripción se solicita, deberá suspender ésta» (RDGRN de 28 de octubre de 2015). 
«La normativa aplicable a la acreditación en sede registral del ordenamiento extranjero debe buscarse, en primer término, en el artículo $36 \mathrm{RH}$, norma que regula los medios de prueba del Derecho extranjero en relación con la observancia de las formas y solemnidades extranjeras y la aptitud y capacidad legal necesarias para el acto", como señala la RDGRN de 1 de marzo de 2005, y resulta también extensible a la acreditación de la validez del acto realizado según la ley que resulte aplicable. Con arreglo al párrafo segundo de este precepto, los medios de prueba del derecho extranjero son «la aseveración o informe de un notario o cónsul español o de diplomático, cónsul o funcionario competente del país de la legislación que sea aplicable». El precepto señala además que "por los mismos medios podrá acreditarse la capacidad civil de los extranjeros que otorguen en territorio español documentos inscribibles». La enumeración expuesta no contiene un numerus clausus de medios de prueba ya que el precepto permite que la acreditación del ordenamiento extranjero podrá hacerse, «entre otros medios», por los enumerados (Calvo Caravaca y Carrascosa González, 2017a: 640).

Por otro lado, al igual que en sede judicial, la doctrina de la DGRN mantiene la exigencia contenida en el art. 281.2 LEC, según la cual no solo es necesario acreditar el contenido del derecho extranjero, sino también su vigencia (véanse, entre otras, SSTS de 11 de mayo de 1989, 7 de septiembre de 1990 y 25 de enero de 1999, RDGRN de 20 de enero de 2011 y 15 de febrero de 2016). Es decir, no basta la cita aislada de textos legales extranjeros sino que, por el contrario, debe probarse el sentido, alcance e interpretación actuales atribuidos por la jurisprudencia del respectivo país (Calvo Caravaca y Carrascosa González, 2017a: 640-641).

Asimismo, la DGRN ha señalado en diferentes ocasiones que las autoridades públicas que desarrollan funciones no jurisdiccionales (arts. 281 LEC, 168.4 RN y 36 párrafo segundo $\mathrm{RH}$ ) pueden realizar bajo su responsabilidad una valoración respecto de la alegación de la ley extranjera, aunque no resulte probada por las partes, siempre que posea conocimiento de la misma (véanse, entre otras, RRDGRN de 14 de diciembre de 1981 y 5 de febrero y 1 de marzo de 2005). «La indagación sobre el contenido del ordenamiento extranjero no constituye en absoluto una obligación del registrador, o del resto de autoridades no judiciales ante las que se inste la aplicación de un ordenamiento extranjero, sino una mera facultad, que podrá ejercerse incluso aunque aquél no sea invocado por las partes». En consecuencia, como señalaron las RRDGRN de 20 de enero y 15 de julio de 2011, «el registrador, pese a que quien insta la inscripción no acredite el contenido del ordenamiento extranjero de acuerdo a los imperativos expuestos, podrá aplicar un Derecho extranjero si tiene conocimiento de él o indaga su contenido y vigencia. En caso contrario, deberá suspender la inscripción» (RDGRN de 3 mayo de 2016 [aplicación del de- 
recho togolés al régimen económico matrimonial], RDGRN de 5 de marzo de 2018). Así lo establece, de forma expresa el párrafo tercero del art. $36 \mathrm{RH}$ cuando establece que «el registrador podrá, bajo su responsabilidad, prescindir de dichos medios si conociere suficientemente la legislación extranjera de que se trate, haciéndolo así constar en el asiento correspondiente».

\section{b. Carácter privativo de un bien inmueble en un régimen de comunidad}

Si uno de los cónyuges compra con carácter privativo un bien inmueble estando casado en un régimen económico de comunidad de bienes, la DGRN exige que se haga constar el carácter privativo del bien en el momento de la adquisición y no en el momento posterior de su enajenación a un tercero; con lo cual en el momento de la compra deberá acreditarse el derecho extranjero al que se somete su régimen económico (RDGRN de 10 de mayo de 2017, en relación con un matrimonio entre un ruso y una ucraniana casados en Ucrania que manifestaban estar sujetos el régimen económico ucraniano y que el bien adquirido era privativo de la esposa, sin que se hubiera probado la aplicación del derecho ucraniano a la economía conyugal).

La RDGRN de 3 de mayo de 2016 debía determinar si era necesario haber demandado y requerido de pago a la esposa de un demandado de nacionalidad togolesa para poder inscribir un decreto de adjudicación de finca como consecuencia de un procedimiento de ejecución hipotecaria. Según el historial registral, la finca estaba inscrita «a favor de D. T., casado bajo el régimen matrimonial que le sea aplicable, de conformidad con lo establecido en artículo 92 del Reglamento Hipotecario y que según manifestó es de separación de bienes». Ello suponía que, de acuerdo con el art. 9.2 CC, la ley aplicable respecto del comprador sería la togolesa como ley personal común de los cónyuges al tiempo de contraerlo, como resultaba del propio título adquisitivo, y, por tanto, para otorgar la escritura pública por la que se hipotecó la vivienda, y para practicar, en su caso, la ulterior inscripción registral, el notario y la registradora debieron conocer el régimen económico matrimonial del hipotecante, al objeto de determinar si gozaba por sí solo de facultades dispositivas.

Según doctrina reiterada de la DGRN, "de conformidad con las determinaciones legales, una vez practicado un asiento el mismo se encuentra bajo la salvaguardia de los tribunales produciendo todos sus efectos en tanto no se declare su inexactitud bien por la parte interesada, bien por los tribunales de Justicia de acuerdo con los procedimientos legalmente establecidos (arts. 1, 38, 40 y $82 \mathrm{LH}$ )», en virtud del principio de legitimación, y en relación con la eficacia de los asientos registrales hay que señalar que su contenido se presume exacto y válido. Por ello, la DGRN confirmó que habiendo el interesado, nacional togolés, constituido e inscrito la hipoteca a su favor en virtud del 
régimen de separación de bienes, no se le podía exigir posteriormente que se demandara y requiriera de pago a su esposa cuando el bien constaba inscrito a su nombre con carácter privativo, reforzando también este criterio el hecho de que la finca en cuestión no era su vivienda familiar habitual según constaba en el historial registral y en la nota simple expedida. De este modo, dado que en el momento de la adquisición del bien se había probado el régimen económico del matrimonio, el titular registral podía disponer de su bien sin consentimiento de su cónyuge.

\section{CONSECUENCIAS DE NO HACER CONSTAR EL RÉGIMEN ECONÓMICO MATRIMONIAL}

Cuando no se hace constar el régimen económico matrimonial del vendedor, la consecuencia es la suspensión de la inscripción solicitada. En la RDGRN de 28 de octubre de 2015 se discutía si era inscribible una escritura de compraventa en la que uno de los vendedores era extranjero, concretamente de nacionalidad estadounidense, quien manifestaba que su estado civil era de casado, pero sin indicar cuál era el régimen económico que regía las relaciones patrimoniales de su matrimonio. La DGRN le dio la razón al registrador que no inscribió la compraventa por los siguientes motivos:

1. No se hacía constar correctamente la nacionalidad del vendedor, pues la nacionalidad norteamericana como tal no existe, debiendo especificarse a qué país de América del Norte ha de atribuirse la nacionalidad y la expedición del pasaporte en cuya virtud se le identifica. 2. No se hacía constar el régimen económico matrimonial del citado vendedor. Este dato se hace preciso pues, aun cuando la adquisición se produjo por título sucesorio, siendo ya extranjero al tiempo de la misma, según constaba en los libros del Registro, se hizo constar que estaba casado pero no su régimen económico matrimonial sin que, precisamente por el elemento de extranjería, pueda aplicársele la presunción de ganancialidad que habitualmente se emplea para quienes ostentan la nacionalidad española. Así, en efecto, el bien ya figuraba inscrito como privativo, pero, como no se había podido identificar su régimen económico matrimonial no podía practicarse la inscripción de la venta pues se desconocía si con arreglo a aquél podía, por sí solo, aun estando casado, disponer el referido bien, razón por la que el artículo 51.9.a del Reglamento Hipotecario exige la constancia de este dato en las inscripciones y, por tanto, en el título presentado, por indicación del artículo 21 de la Ley Hipotecaria.

En la RDGRN de 3 febrero de 2014 se señaló que, al no constar acreditado ante la registradora cuál era el contenido vigente del derecho positivo extranjero aplicable — en este caso, el ordenamiento ruso- con relación a la necesidad de contar con el consentimiento de la esposa para realizar actos 
dispositivos sobre una vivienda adquirida constante matrimonio y vigente su régimen económico matrimonial legal, había que denegar la inscripción. Un ciudadano de nacionalidad rusa hipotecó una vivienda, que fue adquirida por el mismo, casado en régimen de comunidad de bienes vigente en Rusia con una mujer también de nacionalidad rusa, compra que se realizó como «bien común de su sociedad conyugal». Ello suponía que, de acuerdo con el artículo 9.2 CC, la ley aplicable respecto del comprador sería la rusa como ley personal común de los cónyuges al tiempo de contraerlo, como resulta del propio título adquisitivo, y, por tanto, para otorgar la escritura pública por la que se hipoteca la vivienda, y para practicar, en su caso, la ulterior inscripción registral, el notario y la registradora debían conocer el régimen económico matrimonial del hipotecante, al objeto de determinar si gozaba por sí solo de facultades dispositivas.

\section{INMUEBLES INSCRITOS SIN CONSTANCIA DEL RÉGIMEN ECONÓMICO MATRIMONIAL DE SUS PROPIETARIOS Y EJECUCIÓN HIPOTECARIA}

Como se ha visto, en el Registro de la Propiedad español puede constar un bien inmueble a nombre de cónyuges extranjeros, pero sin que se precise el concreto régimen matrimonial de los mismos ni las cuotas que se les atribuyen. Ello comporta graves problemas a la hora de practicar embargos sobre el mismo. En efecto, no se puede saber, de los datos del Registro, en qué proporción pertenece el bien a cada cónyuge. La DGRN ha propuesto varias soluciones (Calvo Caravaca y Carrascosa González, 2017b: 256).

a) Demanda o apremio dirigido contra ambos cónyuges o notificado al otro cónyuge sin prueba del derecho extranjero. El art. 144.6 RH, redactado con arreglo a la disposición final 4. ${ }^{\circ}$ de la Ley 13/2012, de 26 diciembre de 2012, de lucha contra el empleo irregular y el fraude a la Seguridad Social, y vigente desde el 28 diciembre 2012, precisa que cuando se trate de bienes inscritos conforme al art. $92 \mathrm{RH}$, «a favor de adquirente o adquirentes casados sometidos a legislación extranjera, con sujeción a su régimen matrimonial, se haya o no indicado dicho régimen, el embargo será anotable sobre el bien o participación indivisa del mismo inscrita en tal modo, siempre que conste que la demanda o el apremio han sido dirigidos contra los dos cónyuges, o que estando demandado o apremiado uno de los cónyuges ha sido notificado al otro el embargo». Por tanto, se anota el embargo trabado sobre la totalidad de los bienes, aunque no se sepa a quién pertenecen y en qué proporción tales bienes se embargan (RDGRN de 10 de diciembre de 2014 [embargo de finca de ciudadano nigeriano]). Se presupone, por tanto, que el régimen económico matrimonial es de gananciales o un régimen análogo (Garcimartín Alférez, 2013: 196). 
El legislador ha aceptado esta solución, que era la que había forjado la DGRN en sólida práctica registral (RDGRN de 12 de marzo de 2012 [cónyuges rusos], RDGRN de 21 de enero de 2011 [cónyuges rumanos], RDGRN de 3 de agosto de 2006 y RDGRN de 7 de agosto de 2006, RDGRN de 10 de julio de 2006, RDGRN de 24 de noviembre de 2006, RDGRN de 19 de enero de 2007, RDGRN de 22 de enero de 2007, RDGRN de 23 de enero de 2007, RDGRN de 1 de febrero de 2007, RDGRN de 15 de marzo de 2007 [embargo de inmueble rústico propiedad de cónyuges holandeses], RDGRN de 16 de marzo de 2007 [embargo de inmueble propiedad de cónyuges marroquíes], RDGRN de 15 de marzo de 2007 [embargo de inmueble propiedad de cónyuges suizos], RDGRN de 10 de abril de 2007 [cónyuges rusos y embargo instado por la Tesorería General de la Seguridad Social por deudas contraídas por el marido], RDGRN de 30 de abril de 2007 [embargo de finca adquirida por cónyuge brasileña para su régimen matrimonial], RDGRN de 7 de junio de 2007 [embargo sobre inmueble propiedad de cónyuges belgas], RDGRN de 15 de junio de 2007 [cónyuges de nacionalidad sueca], RDGRN de 15 de junio de 2007 [cónyuges de nacionalidad holandesa], RDGRN de 25 de junio de 2007 [cónyuges de nacionalidad francesa], RDGRN de 26 de junio de 2007 [cónyuges de nacionalidad francesa], RDGRN de 28 de agosto de 2008 [cónyuges senegaleses], RDGRN de 29 de agosto de2008 [cónyuges senegaleses]).

La solución funciona así: 1) El solicitante del embargo dirige su petición de embargo contra ambos cónyuges; 2) El embargo se inscribe en el Registro de la Propiedad español; 3) En el caso de que la anotación concluyera con la venta forzosa de la finca, el funcionario correspondiente, esto es, el juez, podrá defender los intereses del sujeto auténtico propietario del bien injustamente embargado si dicho sujeto no comparece en el proceso (Calvo Caravaca y Carrascosa González, 2017b: 256).

b) Embargo de la propiedad del deudor previa prueba del derecho extranjero. Es más criticable otra solución adoptada por la DGRN que consiste en que, cuando se solicita anotación de embargo preventivo sobre bien inmueble que pertenece a ambos cónyuges, el solicitante del embargo debe previamente acreditar cuál es el régimen económico del matrimonio con arreglo al derecho extranjero al que remiten los arts. 9.2 y 9.3 CC. Solo así podrá determinarse a qué cónyuge pertenece el bien y en qué proporción. El solicitante del embargo debe alegar y probar el derecho extranjero aplicable. A falta de alegación y prueba del derecho extranjero aplicable, si el embargo se dirige solo contra uno de los cónyuges, no basta la mera notificación del embargo al otro cónyuge. En tal caso, esto es, si no se ha probado el concreto derecho extranjero y, en consecuencia, no queda acreditado cuál es el concreto régimen económico matrimonial de los cónyuges, y se procede a una mera notificación 
del embargo al otro cónyuge, entonces el registrador debe rechazar la anotación preventiva del embargo sobre la finca (RDGRN de 5 de marzo de 2018 [embargo de finca perteneciente a un nacional portugués], RDGRN de 7 de marzo de 2013 [embargo de inmueble propiedad de cónyuges bolivianos], RDGRN de 22 de julio de 2011 [embargo de finca perteneciente a sujeto marroquí casado], RDGRN de 12 de marzo de 2012 [cónyuges rusos]). Naturalmente, si se trata de un bien inmueble privativo, y así se acredita con arreglo al derecho español o extranjero que rige el régimen económico matrimonial, será suficiente la mera notificación del embargo al otro cónyuge no propietario que comparte el bien como vivienda habitual (art. 144.5 RH) (Calvo Caravaca y Carrascosa González, 2017b: 256).

\section{CÓNYUGES SIN RÉGIMEN ECONÓMICO MATRIMONIAL}

Si no existe «régimen económico matrimonial» en el derecho extranjero aplicable ex arts. 9.2 y 3 CC o arts. 22 y 26 RREM — como sucede en el derecho inglés, en el que existe "separación de bienes» y no hay ninguna comunidad de bienes de tipo germánico; o como ocurre en el derecho marroquí en virtud del cual los matrimonios no se rigen bajo ningún régimen económico-, y dicha circunstancia queda acreditada según el derecho extranjero aplicable, el art. $54 \mathrm{RH}$ ordena inscribir el bien inmueble, fijando la «cuota indivisa" correspondiente a cada uno de los adquirentes (RDGRN de 12 de febrero de 2004, de 19 de diciembre de 2003, SAP de Alicante de 15 de diciembre de 2005).

\section{MENCIONES UTILIZADAS POR LOS NOTARIOS ESPAÑOLES PARA HACER CONSTAR EL RÉGIMEN ECONÓMICO MATRIMONIAL}

\subsection{La mención de adquisición «para su régimen de gananciales»}

En ocasiones, algunos notarios españoles hacen constar en las escrituras de adquisición de los inmuebles sitos en España que los cónyuges extranjeros, con frecuencia alemanes, adquieren "para su régimen de gananciales» o "para su régimen de gananciales alemán». Esta precisión puede no ser correcta, ya que el régimen supletorio en Alemania es un «régimen de separación y participación en las ganancias» (Zugewinngemeinschaft). Esta imprecisión puede trasladarse al Registro de la Propiedad cuando se adquieren inmuebles en España, de modo que puede hacerse constar en el Registro que el inmueble ha sido adquirido por cónyuges alemanes cuyo régimen económico matrimonial es una «sociedad de gananciales» cuando, realmente, no es ese el régimen económico matrimonial de tales cónyuges. Por ello, la RDGRN de 31 de 
agosto de 2017 no acepta sin más que dos cónyuges de nacionalidad alemana adquirieran conforme al régimen económico legal de su nacionalidad, al no precisarse cuál era dicho régimen.

\subsection{La mención «en el régimen legal de su nacionalidad»}

Otras veces los notarios hacen constar en las escrituras de compraventa de una finca a un matrimonio casado "en régimen legal de su nacionalidad» a pesar de que los cónyuges no tengan nacionalidad común. En la RDGRN de 4 de diciembre de 2015 (también en la RDGRN de 5 de marzo de 2007) el registrador denegó la inscripción dado que el cónyuge era de nacionalidad marroquí, y ella, de nacionalidad estadounidense, manifestando el matrimonio estar casado «en el régimen legal de su nacionalidad». Por ello, se entendió que era necesario aclarar cuál era el régimen económico matrimonial que ostentaban dichos consortes, y en función del mismo, debía expresarse la proporción en que los compradores habían adquirido la finca trasmitida. Al tratarse de un matrimonio con esposos de distinta nacionalidad se exige determinar, por manifestación del adquirente o adquirentes, la ley aplicable a su régimen económico matrimonial.

\section{INSCRIPCIÓN DEL RÉGIMEN ECONÓMICO DEL MATRIMONIO EN EL REGISTRO CIVIL ESPAÑOL}

\section{PUBLICIDAD DEL RÉGIMEN ECONÓMICO DEL MATRIMONIO, EN DEFECTO DE CAPITULACIONES MATRIMONIALES}

Como acaba de señalarse, la publicidad del régimen económico matrimonial es una cuestión de gran relevancia frente a los terceros que contratan con los cónyuges. Con carácter general, el régimen económico del matrimonio será el que los cónyuges estipulen en capitulaciones matrimoniales que figurarán al margen de la inscripción de matrimonio. A falta de estas, el régimen económico matrimonial será el que corresponda según la ley aplicable a los efectos del matrimonio. Hay que recordar que esta ley será: la ley personal común de los cónyuges al tiempo de contraerlo; en defecto de esta ley, la ley personal o de la residencia habitual de cualquiera de ellos, elegida por ambos en documento auténtico otorgado antes de la celebración del matrimonio; a falta de esta elección, la ley de la residencia habitual común inmediatamente posterior a la celebración, o a falta de dicha residencia, la del lugar de celebración del matrimonio, si se celebra con anterioridad al 29 de enero de 2019 (art. 9.2 CC); o la ley del Estado en el que los cónyuges o futuros cónyuges, 
o uno de ellos, tengan su residencia habitual en el momento de la celebración del acuerdo o la del Estado de la nacionalidad de cualquiera de los cónyuges o futuros cónyuges en el momento en que se celebre el acuerdo, elegidas en un acuerdo por escrito, fechado y firmado por ambos cónyuges (art. 22 RREM), $y$, en defecto de elección de ley, la ley de primera residencia habitual común tras la celebración del matrimonio o, de no existir, la ley nacional común de los cónyuges en el momento de celebración del matrimonio, o, en su defecto, la ley con la que ambos cónyuges tengan la conexión más estrecha en el momento de la celebración del matrimonio, teniendo en cuenta todas las circunstancias, si se celebra después del 29 de enero de 2019 (art. 26 RREM).

\section{PUBLICIDAD DE LAS CAPITULACIONES MATRIMONIALES}

En el caso de la existencia de pactos o capitulaciones matrimoniales sobre régimen económico del matrimonio, serán válidos siempre que sean conformes bien a la ley que rija los efectos del matrimonio (art. 9.2 CC), bien a la ley de la nacionalidad o bien a la de la residencia habitual de cualquiera de las partes al tiempo del otorgamiento (art. 9.3 CC) para los matrimonios celebrados hasta el 29 de enero de 2019; o conformes a la ley del Estado en el que los cónyuges o futuros cónyuges, o uno de ellos, tengan su residencia habitual en el momento de la celebración del acuerdo o a la del Estado de la nacionalidad de cualquiera de los cónyuges o futuros cónyuges en el momento en que se celebre el acuerdo, elegidas en un acuerdo por escrito, fechado y firmado por ambos cónyuges (art. 22 RREM), y, en defecto de elección de ley, si son conformes a la ley de primera residencia habitual común tras la celebración del matrimonio o, de no existir, la ley nacional común de los cónyuges en el momento de celebración del matrimonio, o, en su defecto, la ley con la que ambos cónyuges tengan la conexión más estrecha en el momento de la celebración del matrimonio, teniendo en cuenta todas las circunstancias, siempre que las capitulaciones matrimoniales se expresen por escrito, fechadas y firmadas por ambos cónyuges (art. 25 RREM) si se celebra después del 29 de enero de 2019 (at. 26 RREM).

Pues bien, esta ley reguladora de los pactos o capitulaciones matrimoniales es la que debe determinar si es necesaria la inscripción de los mismas en algún registro oficial «como requisito para su validez» o como «requisito para su oposición frente a terceros».

De aplicarse la ley española a la validez de los pactos o capitulaciones matrimoniales, hay que tener en cuenta que, por un lado, el art. 1327 CC exige para la validez de las capitulaciones matrimoniales su formalización en escritura pública, y que, por otro lado, el art. 77 de la LRC no exige que las capitulaciones matrimoniales sean objeto de inscripción. 
Ahora bien, es la ley aplicable a la oponibilidad del régimen económico matrimonial pactado en capitulaciones matrimoniales la que debe concretar las «modalidades» de la publicidad registral: inscripción, mención, anotación y efectos de dichas modalidades de acceso a los registros públicos. Esta ley aplicable a la publicidad de los actos de transmisión de los derechos reales que recaen sobre bienes concretos y determinados es la ley del lugar donde se hallen los bienes inmuebles, en virtud del art. 10.1 CC (Calvo Caravaca y Carrascosa González, 2017b: 251).

Veamos por separado cada uno de estos problemas.

\subsection{Indicación registral voluntaria de las capitulaciones matrimoniales}

Así, respecto a la validez de las capitulaciones matrimoniales, el art. 77-I LRC establece que «al margen también de la inscripción del matrimonio podrá hacerse indicación de la existencia de pactos, resoluciones judiciales y demás hechos que modifiquen el régimen económico de la sociedad conyugal». Por tanto, las capitulaciones matrimoniales no son objeto de inscripción en sentido estricto (art. 1 LRC), sino de una mera indicación (arts. 77 LRC y 266 RRC). Ni siquiera es obligatoria su constancia registral, pues solo se extenderán a instancia de los interesados y con carácter voluntario, pese a los términos imperativos de los artículos que se refieren a ellas (art. $1.333 \mathrm{CC}$ ), términos que la doctrina interpreta y justifica en el sentido de que constituyen un requisito necesario para que puedan producir efectos respecto de terceras personas. El art. 1333 CC señala que «en toda inscripción de matrimonio en el Registro civil se harán mención, en su caso, de las capitulaciones matrimoniales que se hubieren otorgado, así como de los pactos, resoluciones judiciales y demás hechos que modifiquen el régimen económico del matrimonio. Si aquéllas o éstos afectaren a inmuebles, se tomará razón en el Registro de la Propiedad, en la forma y a los efectos previstos en la Ley Hipotecaria».

Ahora bien, si no se procede a tal «mención», los terceros de buena fe no resultarán perjudicados, en ningún caso, por unas capitulaciones o pactos patrimoniales que no consten «indicados» en el Registro Civil (Calvo Caravaca y Carrascosa González, 2017b: 253).

La «mención» equivale a la «indicación» aludida por el art. 77 LRC y sigue el mismo régimen jurídico que la «inscripción», pero no tiene el valor jurídico de esta; por ello, la «indicación» no hace prueba de los hechos indicados (art. 2 LRC a sensu contrario). A través de dicha indicación registral se articula y se facilita la adecuada coordinación del Registro Civil con la publicidad propia del Registro de la Propiedad en aquellos casos en que los bienes de los cónyuges tienen naturaleza inmobiliaria (art. 266-IV RRC, 
STS de 26 de mayo de 1994 y RDGRN de 12 de mayo de 2005). Pero esta «indicación registral» no expresa el contenido de las capitulaciones, con lo cual los terceros saben que hay unas capitulaciones matrimoniales válidas, pero no su contenido. Para conocer el contenido deben acudir al protocolo notarial correspondiente o solicitar al interesado el documento donde conste el contenido de las capitulaciones. Según el art. 266.VII RRC, los notarios españoles expedirán copias de las estipulaciones que afecten al régimen económico matrimonial «a cualquier solicitante que presente un principio de prueba que le acredite como titular de algún derecho patrimonial frente a cualquiera de los cónyuges».

Hay que tener en cuenta que esta mención registral solo es posible si el matrimonio es inscribible en el Registro Civil español, aunque las capitulaciones matrimoniales se rijan por una ley extranjera (Garcimartín Alférez, 2013: 195). Pues bien, la RDGRN de 9 de enero de 2008, en relación con unas capitulaciones de cónyuges de nacionalidad chilena y argentina y adquisición de un bien inmueble sito en España, señaló que «los matrimonios de extranjeros celebrados en el extranjero no tienen acceso al Registro civil español» y, en consecuencia, las capitulaciones otorgadas por estos cónyuges extranjeros ante notario español tampoco eran inscribibles en el Registro Civil español. Y, aunque estas capitulaciones matrimoniales no tengan acceso al Registro Civil español, «han de tenerse por plenamente válidas y eficaces en nuestro ordenamiento jurídico», pues lo contrario "conduciría a resultados no razonables y gravemente perjudiciales para la seguridad jurídica en general y la del tráfico en particular» (Rivas Andrés, 2008: 58).

\subsection{Validez de las capitulaciones matrimoniales otorgadas en el extranjero}

Por su parte, el art. 1327 del CC exige para la validez de las capitulaciones matrimoniales su formalización en escritura pública. Cuando las capitulaciones se han otorgado en el extranjero, hay que valorar la validez del documento. Para ello se hace necesaria una labor previa de comparación entre los requisitos básicos exigidos al documento extranjero para gozar de ese mismo valor público en su propio Ordenamiento. Solo cuando el documento extranjero reúna los requisitos o presupuestos mínimos imprescindibles que caracterizan al documento público español, podrá sostenerse que aquel resulta apropiado para permitir la inscripción en el Registro Civil del convenio capitular en el mismo contenido, de acuerdo con lo que se ha venido a denominar en la doctrina como «equivalencia de las formas».

El documento público español alcanza este valor cuando en él concurren las exigencias básicas siguientes, según la RDGRN de 23 de noviembre de 2006: 
a) Que haya sido autorizado "por un notario o empleado público competente» (art. $1216 \mathrm{CC}$ ), es decir, que el funcionario autorizante sea el titular de la función pública de dar fe, bien en la esfera judicial, bien en la esfera extrajudicial.

b) Que se hayan observado «las solemnidades requeridas por la Ley» (art. 1216 CC), lo que se traduce en el cumplimiento de las formalidades exigidas para cada categoría de documento público. Según la legislación española se hará mención a las capitulaciones matrimoniales otorgadas, antes o después del matrimonio, en escritura pública; requisito imprescindible para su validez, sin que se prevea ninguna otra mención sobre el régimen económico del matrimonio (RDGRN de 21 de noviembre de 2011, en relación a un matrimonio de marroquíes que no había acreditado el régimen legal de los matrimonios marroquíes. Según el marido, el derecho marroquí lo sometía al principio de separación de bienes, cuando en realidad en Marruecos los matrimonios no se rigen bajo ningún régimen económico). «Cuando se trata de documentar públicamente un acto extrajudicial, son sustancialmente la necesidad de la identificación suficiente del otorgante del acto o contrato (fe de conocimiento o juicio de identidad) y la apreciación por el autorizante de la capacidad del otorgante (juicio de capacidad)» (RDGRN de 21 de noviembre de 2011). Por otra parte, el documento extranjero habrá de estar traducido y legalizado o apostillado (art. 81 RRC).

Finalmente, en cuanto al acceso al Registro Civil español de unas capitulaciones matrimoniales otorgadas en el extranjero, de acuerdo con lo establecido en el art. 15 LRC, constarán en el Registro Civil español los hechos inscribibles que afectan a los españoles y los ocurridos en territorio español aunque afecten a extranjeros. Por tanto, las capitulaciones otorgadas en el extranjero tendrán acceso al Registro solo si el matrimonio es inscribible en el Registro Civil español. Y aunque el mismo artículo contiene la previsión de práctica de una inscripción soporte de hechos ocurridos fuera de España cuando tal asiento deba servir de base a inscripciones marginales exigidas por el derecho español, lo cierto es que la existencia de capitulaciones matrimoniales no es objeto de inscripción tal y como se ha señalado anteriormente.

La inscripción de las capitulaciones matrimoniales en un registro civil extranjero no es oponible a terceros de buena fe en España, ya que la publicidad registral presenta un alcance limitado al territorio del Estado del que depende el registro (Calvo Caravaca y Carrascosa González, 2017b: 250; Carrillo Pozo, 2011: 108; Rodríguez Rodrigo, 2017: 610). 


\subsection{Discrepancia entre lo inscrito en el Registro Civil y lo inscrito en el Registro de la Propiedad}

Como se ha señalado con anterioridad, hay que dar publicidad de las capitulaciones matrimoniales en el Registro de la Propiedad español. Señala el art. $75 \mathrm{RH}$ :

De conformidad con el artículo 1333 del Código civil, serán inscribibles en el Registro de la Propiedad las capitulaciones matrimoniales en cuanto contengan respecto a bienes inmuebles o derechos reales determinados, alguno de los actos a que se refieren los artículos 2 de la Ley y 7 de este Reglamento. Si, en tal caso, el matrimonio no se hubiere contraído, se suspenderá la inscripción y podrá tomarse anotación preventiva de suspensión, que se convertirá en inscripción cuando se acredite la celebración de aquél o se cancelará a solicitud de cualquiera de los otorgantes si, transcurridos un año y dos meses desde la fecha de las capitulaciones, no se hubiere acreditado que el matrimonio se celebró dentro del plazo de un año desde dicha fecha.

En caso de disparidad entre lo inscrito en el Registro Civil y lo inscrito en el Registro de la Propiedad, la DGRN ha señalado que prevalece lo recogido en el Registro de la Propiedad: RDGRN de 14 de mayo de 1984, 3 de junio de 1991 (Carrillo Pozo, 2011: 107; Rodríguez Rodrigo, 2017: 610). Sin embargo, el TS no lo tiene tan claro y da prevalencia a lo inscrito en uno u otro registro siempre sobre la base de la protección del tercero: STS de 26 de mayo de 1994 y de 10 de marzo de 1998 (Carrillo Pozo, 2011: 108; Díaz Fraile, 2002: 1403).

\subsection{Discrepancia entre lo inscrito en el Registro Civil y lo inscrito en el Registro Mercantil español}

También hay que dar publicidad de las capitulaciones matrimoniales en el Registro Mercantil español. En la inscripción primera del empresario individual, cuando se trate de una persona casada, se expresarán, según el art. 92 RRM, además de las circunstancias del art. 90 (1. ${ }^{\circ}$ la identidad del mismo; $2 .^{\circ}$ el nombre comercial y, en su caso, el rótulo de su establecimiento; $3 .^{\circ}$ el domicilio del establecimiento principal y, en su caso, de las sucursales; $4 .^{\circ}$ el objeto de su empresa, $5 .^{\circ}$ la fecha de comienzo de sus operaciones), las siguientes: $1 .^{a}$ la identidad del cónyuge; $2{ }^{a}$ la fecha y lugar de celebración del matrimonio, y los datos de su inscripción en el Registro Civil, $3 .^{a}$ el régimen económico del matrimonio legalmente aplicable o el que resulte de capitulaciones otorgadas e inscritas en el Registro Civil. 
Este precepto es el desarrollo de lo dispuesto en el artículo 22.1 CCo, que señala igualmente:

En la hoja abierta a cada empresario individual se inscribirán los datos identificativos del mismo, así como su nombre comercial y, en su caso, el rótulo de su establecimiento, la sede de éste y de las sucursales, si las tuviere, el objeto de su empresa, la fecha de comienzo de las operaciones, los poderes generales que otorgue, el consentimiento, la oposición y la revocación a que se refieren los artículos 6 a 10; las capitulaciones matrimoniales, así como las sentencias firmes en materia de nulidad, de separación y de divorcio, y los demás extremos que establezcan las Leyes o el Reglamento.

En el caso de discrepancia entre lo publicado en el Registro Civil español y lo publicado en el Registro Mercantil español, la doctrina ha señalado que debe prevalecer lo inscrito en el Registro Civil, teniendo en cuenta el carácter no especializado de las informaciones que suministra el Registro Mercantil en materia de régimen económico del matrimonio (Arenas García, 2000: 89; Carrillo Pozo, 2011: 108). Ahora bien, si el comerciante individual domiciliado en España no tiene inscrito su matrimonio en el Registro Civil español, pueden surgir muchos problemas de desconocimiento que puede dejar desprotegido al tercero de buena fe que contrata con ese comerciante (Carrillo Pozo, 2011: 108).

\section{Bibliografía}

Arenas García, R. (2000). Registro mercantil y Derecho del comercio internacional. Madrid: Colegio de Registradores de la Propiedad y Mercantiles de España.

Barrière Brousse, I. (2017). Le patrimoine des couples internationaux dans l'espace judiciaire européen. Les réglements européens du 24 juin 2016 relatifs aux régimes matrimoniuax et aux effets patrimoniaux des partenariats enregistrés. Clunet, 2, 485-514.

Bonomi, A. (2014). The Proposal for a Regulation on Matrimonial Property: A Critique of the Proposed Rule on the Immutability of the Applicable Law. En K. Boele-Woelki et al. (eds.). Family Law and Culture in Europe: Developments, Challenges and Opportunities (pp. 231-248). Intersentia. DOI: 10.1017/9781780685274.018.

Calvo Caravaca, A. L. y Carrascosa González, J. (2017a). Derecho internacional privado, vol. I. Granada: Comares.

Calvo Caravaca, A. L. y Carrascosa González, J. (2017b). Efectos del matrimonio. En A. L. Calvo Caravaca y J. Carrascosa González, J. (dirs.). Derecho internacional privado, vol. II (pp. 213-270). Granada: Comares.

Campuzano Díaz, B. (2008). La propuesta de reforma del Reglamento 2201/2003 en materia matrimonial. En Hacia un derecho conflictual europeo: realizaciones y perspectivas (pp. 93-11). Sevilla: Universidad de Sevilla. 
Carrillo Pozo, L. F. (2011). Eficacia en España de las resoluciones extranjeras en materia de efectos económicos del matrimonio. Cuadernos de Derecho Transnacional, 1, 86121.

Díaz Fraile, J. M. (2002). Breve esbozo de una teoría general sobre los principios registrales civiles. Particular estudio de la publicidad material del Registro Civil. Revista Crítica de Derecho Inmobiliario, 78 (672), 1367-1404.

Farrugia, M. (2011). The future EU Regulation concerning Matrimonial Property Regimes. En B. Campuzano Díaz et al. (eds.). Latest Developments in EU Private International Law (pp. 63-82). Intersentia.

Garcimartín Alférez, F. J. (2013). Art. 9.2 y 9.3. En R. Bercovitz Rodríguez-Cano (dir.). Comentarios al Código Civil (t. I, pp. 187-196). Valencia: Tirant lo Blanch.

Godechot-Patris, S. (2016). Commentaire du réglement du 24 juin 2016 relatif aux régimes matrimoniaux: le changement dans la continuité. Recueil Dalloz, 39, 22922299.

Jayme, E. (2009). Party autonomy in international family and succession law: new tendencies. Yearbook of Private International Law, 11, 1-10.

Joubert N. (2017). La dernière pierre (provisoire?) à l'édifice du droit international privé europeén en matière familiale. Les règlements du 24 juin 2016 sur les régimes matrimoniaux et les effets patrimoniaux des partenariats enregostrés. Revue critique de droit international privé, 1, 1-26.

Marino, S. (2017). Strengthening the european civil judicial cooperation: the patrimonial effects on family relationships. Cuadernos de Derecho Transnacional, 9 (1), 265-284.

Mingorance Gonsálvez, C. (2010). Registro de la propiedad y régimen económico de los matrimonios extranjeros en España. Revista de Derecho Privado, 94, 59-74.

Péroz, H. y Fongaro, E. (2017). Droit international privé patrimonial de la famille. Pars: Lexis Nexis.

Quinzá Redondo, J. P. (2016). Régimen económico matrimonial. Aspectos sustantivos y confictuales. Valencia: Tirant lo Blanch.

Rivas Andrés, R. (2008). Inscripción en el Registro Civil de capitulaciones de separación de bienes autorizadas por notario español (breves apuntes jurídico/telefónicos). La Notaria, 49-50, 53-59.

Rodríguez Rodrigo, J. (2017). Régimen económico matrimonial en Derecho internacional privado. En M. Yzquierdo Tolsada y M. Cuena Casas (dirs.). Regímenes económicos matrimoniales (II). Derecho de familia y concurso de acreedores. Las parejas no casadas (pp. 489-620). Cizur Menor: Thomson Reuters.

Rodríguez Rodrigo, J. (2018). Régimen económico matrimonial y de las parejas registradas. En A. L. Calvo Caravaca y J. Carrascosa González, J. (dirs.). Derecho internacional privado, vol. II (pp. 161-226). Granada: Comares.

Vismara, F. (2017). Legge applicabile in mancanza di scelta e clausola di eccezione nel regolamento (UE) N. 2016/1103 in materia di regimi patrimoniali tra i coniugi. Rivista di Diritto Internazionale Privato e Processuale, 2, 356-371.

Yetamo, T. M. (2010). The constitututionalization of party autonomy in European family law. Journal of Private International Law, 6 (1), 155-193. Disponible en: https:// doi.org/10.1080/17536235.2010.11424376. 